Review Article

\title{
Scientific framework of homeopathy: Evidence-based Homeopathy
}

\author{
Michel Van Wassenhoven (MD)
}

\author{
Liga Medicorum Homeopathica Internationalis \& European Committee for Homeopathy
}

\begin{abstract}
Paper aims at considering all important aspects of the scientific framework of homeopathic practice, looking at the levels of scientific evidence of each aspect in an objective way, through an extensive review of literature. Levels of evidence considered are: I) existence of meta-analyses and/or systematic positive reviews of literature; IIa) multiple positive randomized controlled trials (RCTs); IIb) some positive RCTs; IIIa) positive multiple cohorts studies; IIIb) positive studies with some cohorts; IV) opinion of experts (clinical and daily practice cases). Conclusions are clear: homeopathy must stay within the framework of medical practice, and it is even a necessity for public health.
\end{abstract}

Keywords: Evidence-Based medicine, Homeopathy, Scientific framework, Literature review

\section{Introduction}

The World Health Organization (WHO) concluded, in a report of 2005 on traditional medicine (TM) in several countries [1], that TM maintains its popularity worldwide. In addition, during the last 10 years, the use of complementary and alternative medicine (CAM) has increased in several countries. The safety of the products employed in CAM, their quality control and evaluation in terms of efficacy are priorities to political authorities as well as the population.

More particularly, the WHO asked questions to its 191 members. 141 countries (74\%) answered. $32 \%$ of them have developed health policies including TM/CAM; 56\% stated that policies regarding TM/CAM are "under construction". Only 5 countries effected regularization before 1990. Moreover, 28\% of countries have a national program specific for TM/CAM and 58\% have established a national committee in charge of TM/CAM.

In most cases, these committees are located in Health Departments. Finally, $43 \%$ of countries have named a committee of experts for TM/CAM. Harmony lacks among countries. Major difficulties include: absence of a standardized educational program for TM/CAM and lack of experts. Countries ask the WHO for support and advice in order to develop national policies for the regularization of TM/CAM.
In Europe, the report "Concerted Action for Complementary and Alternative Medicine Assessment in the Cancer Field" [2], observed the same tendency regarding the increase in the use of CAM. In the United States of America, the Consortium of the Academic Health Centers [3] integrates CAM in 30 university medical centers. As in the United Kingdom, the concept of "integrated" medicine predominates; all possible treatments must be offered to patients. This stance is based on the results of intensive scientific research on CAM. Until this moments, results for homeopathy are very hopeful.

Recent publications show the benefit of homeopathy in hospital care, as well as in emergency services for patients in critical state [4-6]. Authors suggest the development of algorithms including homeopathy, allowing quick and adequate reactions for these patients.

The aim of the present paper is to review the scientific framework of current homeopathic practice worldwide. Scientific accuracy is appraised according to the level of evidence available for each aspect. Levels of evidence considered are: I) existence of meta-analyses and/or systematic positive reviews of literature; IIa) multiple positive randomized controlled trials (RCTs); IIb) some positive RCTs; IIIa) positive multiple cohorts studies; IIIb) positive studies with some cohorts; IV) opinion of experts (clinical and daily practice cases).

Meta-analyses: Systematic review 
The "gold-standard", universally accepted for the evaluation of the efficacy of medicines, is the metaanalysis, or systematic audit of RCTs. Since 1991, 6 comprehensive reviews regarding homeopathy were published. The conclusion of them all was that homeopathy has a positive and specific effect greater than placebo. (Table 1)

Table 1. Comprehensive systematic reviews on homeopathic trials

\begin{tabular}{|c|c|c|}
\hline Source & Studies & Results \\
\hline $\begin{array}{l}\text { Kleijnen et al., } \\
1991 \text { [7] }\end{array}$ & $\begin{array}{l}105 \text { studies with interpretable results. } \\
\text { Meta-analysis based on validated } \\
\text { criteria }\end{array}$ & $\begin{array}{l}-77 \% \text { of studies show positive result of } \\
\text { homeopathy } \\
\text { - regarding quality of trials, results are most } \\
\text { favorable for homeopathy } \\
\text { - "there is valid argument for further evaluation } \\
\text { of homeopathy" }\end{array}$ \\
\hline $\begin{array}{l}\text { Boissel et al., } \\
1996[8]\end{array}$ & $\begin{array}{l}15 \text { studies. Inclusion only of highest } \\
\text { quality studies. }\end{array}$ & $\begin{array}{l}\text {-Combined } p \text {-values for the } 15 \text { studies is } \\
\text { significant }(p=0.0002) \\
\text {-Little evidence for non-published negative } \\
\text { results. } \\
\text {-it is evident that homeopathy is more efficient } \\
\text { than placebo" }\end{array}$ \\
\hline $\begin{array}{l}\text { Linde et al., } \\
1997[9]\end{array}$ & 89 studies & $\begin{array}{l}\text { - Odds ratio combined } 2.45 \text { (95\% CI, 2.05-2.93) in } \\
\text { favor of homeopathy } \\
\text {-Odds ratio for the best } 26 \text { studies was } 1.66 \\
\text {-"it is not possible that the clinical effects of } \\
\text { homeopathy are due completely to placebo" }\end{array}$ \\
\hline $\begin{array}{l}\text { Linde \& } \\
\text { Melchart, } \\
1998[10]\end{array}$ & $\begin{array}{l}32 \text { studies; inclusion only of } \\
\text { individualized homeopathy }\end{array}$ & $\begin{array}{l}\text {-Individualized homeopathy is more efficient than } \\
\text { placebo: value of combined coefficient }=1.62(95 \% \\
\text { CI, 1.17-2.23) } \\
\text {-Further research is justified }\end{array}$ \\
\hline $\begin{array}{l}\text { Cucherat et al, } \\
2000[11]\end{array}$ & $\begin{array}{l}16 \text { trials, representing } 17 \text { comparisons } \\
\text { to placebo (based on Boissel et al.) }\end{array}$ & $\begin{array}{l}\text {-Several studies have positive results; more trials } \\
\text { with positive results than expected by chance } \\
\text { alone } \\
\text {-Publication bias is unlikely } \\
\text {-More clinical trials are needed }\end{array}$ \\
\hline $\begin{array}{l}\text { Shang et al., } \\
2005[12]\end{array}$ & $\begin{array}{l}110 \text { trials included, but conclusions } \\
\text { taken from a few post hoc selected } \\
\text { studies }(n=8,7 \%)\end{array}$ & $\begin{array}{l}\text {-Quality of studies is on average better than } \\
\text { studies with conventional remedies } \\
\text {-No significant effect exist with homeopathic } \\
\text { medicines } \\
\text {-The authors conclusion is based on an } \\
\text { amalgamation of biases (selection, post hoc } \\
\text { criteria and heterogeneity) [16] }\end{array}$ \\
\hline
\end{tabular}


The fact that some meta-analyses have shown positive evidence for homeopathy is remarkable, as meta-analyses are far from appropriate when trials are extremely heterogeneous (as in homeopathy), not only regarding results, but also the interventions and health conditions under study, as well as when a therapeutic system works in some but not all indications.

One study, namely GRECHO's [13] occupies excessive place and exerts considerable influence on the results of all 6 audits, especially in Shang et al.'s $(1 / 7=>15 \%)$, where Opium and Raphanus were administered to stimulate intestine activity after surgery.

Both remedies were compared to placebo and no positive result was obtained. However, individuality
- a basic principle of homeopathy - was not taken into account.

The major problem in this type of analysis is linked to the initial hypothesis: "homeopathy is not better than placebo". Recently, the zero-hypothesis was reformulated as "homeopathy functioned not better than placebo in a specific case". This hypothesis indeed corresponds to systematic conventional research and as such, cannot be contested.

It also represents a solution to the problem of heterogeneity in medical conditions. 17 systematic reviews or meta-analysis focusing RCTs of homeopathy in 15 specific areas were performed. This critical approach was explained by Jonas, Kaptchuk and Linde [14]. Results are described in Table 2.

Table 2. Levels of evidence of 17 systematic reviews of RCTs of homeopathy in 15 specific areas

\begin{tabular}{|l|l|}
\hline Level of evidence & Studies \\
\hline I & $\begin{array}{l}\text { Childhood diarrhea and seasonal allergic rhinitis [14]. Allergic rhinitis [15], post- } \\
\text { operative ileus (16), rheumatoid arthritis [17], protection against toxic substances } \\
{[18]}\end{array}$ \\
\hline IIa & $\begin{array}{l}\text { Asthma [19], fibrositis [20], influenza [21], muscular pain [22], otitis media [23], } \\
\text { several pains [24], side effects of radiotherapy [25], strains [26], NET infections } \\
{[27] .}\end{array}$ \\
\hline IIb & $\begin{array}{l}\text { Anxiety [28], hyperactivity disorders [29,30], irritable bowel [31], migraine [32], } \\
\text { knee osteoarthritis [33], premenstrual syndrome [34], pain association to } \\
\text { unwanted postpartum lactation [35], prevention of nausea and vomiting associated } \\
\text { to chemotherapy [36], septicemia [37] and analgesia post-tonsillectomy [38]. }\end{array}$ \\
\hline
\end{tabular}

While this approach corresponds to the common criteria of conventional medicine, it is very limited in and does not analyze the actual daily practice of a homeopathic GP. Further phases are needed, as general practice involves more than searching for the treatment of a specific disease, it seeks for a global amelioration of the health of the patient. Therefore, a GP applies a broader frame than the treatment of a disease, to take into account other factors (diet, psychological state, activity, environment, etc.) RCTs results have only a very limited influence on the practical choice of a treatment for a specific patient. RCTs are conducted in "ideal artificial situations", far from the particular context of the individual patient. The methods of evaluation must take this reality into account.

\section{Results of "echo studies"}

'ECHO' are surveys looking at Economic, Clinic and Humanistic Outcomes. In the literature, 19 publications using validated scores for quality of life (QOL) are found to evaluate the efficacy of homeopathic medicines, totalizing 19,804 patients. Evidence level IIIa is obtained in all ECHOstudies, all diagnoses merged. (Table 3) 


\begin{tabular}{|c|c|c|c|c|c|}
\hline Condition/Study & $\mathrm{N}$ & Design QOL & Test group & $\begin{array}{l}\text { Control } \\
\text { group }\end{array}$ & Results \\
\hline $\begin{array}{l}\text { Becker-Witt, } \\
\text { et al. } \\
{[48,49]}\end{array}$ & 2851 & $\begin{array}{l}\text { Prospective } \\
\text { observational } \\
\text { MOS SF-36 }\end{array}$ & homeopathy & - & $\begin{array}{l}\text { Significant and relevant } \\
\text { improvement of SF-36 }\end{array}$ \\
\hline $\begin{array}{l}\text { Bordet et al. } \\
{[50]} \\
\text { Menopause } \\
\text { flushes, } \\
6 \text { months }\end{array}$ & 438 & $\begin{array}{l}\text { Prospective } \\
\text { observational. } \\
\text { Multicentric } \\
\text { (99 MD) } \\
\text { Not validated } \\
\text { double QOL score }\end{array}$ & homeopathy & - & $\begin{array}{l}\text { Significant and relevant } \\
\text { improvement on both QOL } \\
\text { scores (daytime / sleep) }\end{array}$ \\
\hline $\begin{array}{l}\text { Dias-Brunini } \\
{[51]} \\
\text { Asthma - } \\
\text { pediatrics } \\
6 \text { months }\end{array}$ & 51 & $\begin{array}{l}\text { Prospective } \\
\text { observational. } \\
\text { AUQEI QOL } \\
\text { score applied to } \\
\text { children. }\end{array}$ & homeopathy & - & $\begin{array}{l}\text { QOL score from } 42.27 \text { to } \\
54.94, \text { significant statistical } \\
\text { increase. }\end{array}$ \\
\hline $\begin{array}{l}\text { Goossens et al } \\
{[52]} \\
\text { Hay fever }\end{array}$ & 74 & $\begin{array}{l}\text { Prospective } \\
\text { observational non } \\
\text { comparative. } \\
\text { RQLQ QOL } \\
\end{array}$ & homeopathy & & $\begin{array}{l}\text { Significant improvement } \\
\text { after } 3 \text { and } 4 \text { weeks. }\end{array}$ \\
\hline $\begin{array}{l}\text { Guthlin et al } \\
{[53]} \\
\text { All conditions } \\
<4 \text { years }\end{array}$ & 951 & $\begin{array}{l}\text { Prospective } \\
\text { observational. } \\
\text { MOS SF-36 }\end{array}$ & homeopathy & . & $\begin{array}{l}\text { Number of patients too small } \\
\text { for valid results. }\end{array}$ \\
\hline $\begin{array}{l}\text { Guthlin et al } \\
{[54]} \\
\text { All conditions } \\
<4 \text { years }\end{array}$ & 750 & $\begin{array}{l}\text { Prospective } \\
\text { observational. } \\
\text { MOS SF-36 }\end{array}$ & homeopathy & - & $\begin{array}{l}\text { QOL improved in most } \\
\text { dimensions highly } \\
\text { significantly }\end{array}$ \\
\hline $\begin{array}{l}\text { Jong et al } \\
{[55]} \\
\text { Respiratory and } \\
\text { ear complaints } \\
7-14-28 \text { days, } \\
\text { final results. }\end{array}$ & 2055 & $\begin{array}{l}\text { Prospective } \\
\text { observational. } \\
\text { HSQ-12; } \\
\text { HSQ-5 }\end{array}$ & homeopathy & conventional & $\begin{array}{l}\text { No significant differences in } \\
\text { duration of illness, response } \\
\text { to treatment, patient } \\
\text { satisfaction and adverse } \\
\text { effects. }\end{array}$ \\
\hline $\begin{array}{l}\text { Riley et al } \\
{[56]} \\
\text { Respiratory and } \\
\text { ear complaints } \\
14-28 \text { days }\end{array}$ & 456 & $\begin{array}{l}\text { Prospective } \\
\text { observational. } \\
\text { HSQ-12; } \\
\text { HSQ-5 }\end{array}$ & homeopathy & conventional & $\begin{array}{l}\text { Homeopathy at least as } \\
\text { effective as conventional } \\
\text { medical care }(64.3 \% \\
><56.6 \%) \text {. Adverse effects } \\
7.8 \% \text { versus } 22.3 \% .\end{array}$ \\
\hline $\begin{array}{l}\text { Hochstrasse } \\
{[57]} \\
\text { pregnancy } \\
<9 \text { months }\end{array}$ & 205 & $\begin{array}{l}\text { Prospective } \\
\text { observational } \\
\text { comparative. } \\
\text { SEIQoL }\end{array}$ & homeopathy & conventional & $\begin{array}{l}\text { Lower QOL in the } \\
\text { homeopathic group ( } 2 \\
\text { different populations, } \\
\text { comparison impossible) }\end{array}$ \\
\hline $\begin{array}{l}\text { Muscari-Tomaioli } \\
\text { et al } \\
{[58]}\end{array}$ & 53 & $\begin{array}{l}\text { Prospective } \\
\text { observational. } \\
\text { MOS SF-36 }\end{array}$ & homeopathy & - & $\begin{array}{l}\text { Mean and median scores of } \\
\text { all QOL dimensions rose. } \\
\text { Strongest results in "bodily }\end{array}$ \\
\hline
\end{tabular}




\begin{tabular}{|c|c|c|c|c|c|}
\hline $\begin{array}{l}\text { Headache } \\
6 \text { months }\end{array}$ & & & & & $\begin{array}{l}\text { pain" and "vitality" } \\
\text { parameters p<0.0001 }\end{array}$ \\
\hline $\begin{array}{l}\text { Spence et al } \\
{[59]} \\
\text { Wide range of } \\
\text { Chronic } \\
\text { conditions }\end{array}$ & 6544 & $\begin{array}{l}\text { Prospective } \\
\text { observational }\end{array}$ & homeopathy & - & $\begin{array}{l}\text { Positive health changes in } \\
\text { routine homeopathic hospital } \\
\text { practice }\end{array}$ \\
\hline $\begin{array}{l}\text { Strosser et al } \\
{[60]} \\
\text { Vertigo } \\
6 \text { weeks }\end{array}$ & 119 & $\begin{array}{l}\text { Double-blind } \\
\text { comparative } \\
\text { MOS SF-36 }\end{array}$ & 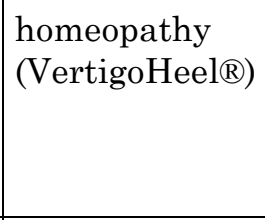 & $\begin{array}{l}\text { conventional } \\
\text { (betahistins) }\end{array}$ & $\begin{array}{l}\text { Significant amelioration of } \\
\text { physical and mental health } \\
\text { with homeopathy. Equivalent } \\
\text { efficacy in the } 2 \text { groups }\end{array}$ \\
\hline $\begin{array}{l}\text { Thompson et al } \\
\text { [61] } \\
\text { Cancer } \\
5 \text { consultations } \\
\text { later }\end{array}$ & 52 & $\begin{array}{l}\text { Prospective } \\
\text { observation } \\
\text { EORTC QLQ-30 } \\
\text { QOL score }\end{array}$ & homeopathy & - & Improvement in $75 \%$ patients \\
\hline $\begin{array}{l}\text { Thompson et al } \\
\text { [62] } \\
\text { Management of } \\
\text { oestrogen } \\
\text { withdrawal in } \\
\text { women with } \\
\text { breast cancer }\end{array}$ & 40 & $\begin{array}{l}\text { Prospective } \\
\text { observational }\end{array}$ & homeopathy & - & $\begin{array}{l}\text { Significant improvement in } \\
\text { anxiety, depression and QOL }\end{array}$ \\
\hline $\begin{array}{l}\text { Anelli et al } \\
{[63]} \\
\text { All conditions } \\
6 \text { months }\end{array}$ & 1025 & $\begin{array}{l}\text { Prospective } \\
\text { observational } \\
\text { MOS SF-36 \& } \\
\text { DUKE QOL } \\
\text { scores }\end{array}$ & homeopathy & & $\begin{array}{l}\text { QOL score differences: } \\
\text { Allergy +7.987; General } \\
\text { problems +10.198; Bowels } \\
+8.189 ; \text { Muscles \& bones } \\
+0.764 ; \text { Stress, anxiety, } \\
\text { sadness +6.041; Nose, ears } \\
\text { +4.677; Skin +6.395. small } \\
\text { but statistically significant } \\
\text { improvement. }\end{array}$ \\
\hline $\begin{array}{l}\text { Weber et al } \\
{[64]} \\
\text { Acute sinusitis }\end{array}$ & 63 & $\begin{array}{l}\text { Non-randomized } \\
\text { clinical trial } \\
\text { HCG-5 QOL score }\end{array}$ & $\begin{array}{l}\text { homeopathy }+ \\
\text { herbal therapy }\end{array}$ & conventional & $\begin{array}{l}\text { Equally effective (or } \\
\text { ineffective) }\end{array}$ \\
\hline $\begin{array}{l}\text { White et al } \\
{[65]} \\
\text { Asthma- } \\
\text { pediatrics }\end{array}$ & 96 & $\begin{array}{l}\text { Randomized } \\
\text { placebo controlled } \\
\text { QOL subscale of } \\
\text { Childhood } \\
\text { Asthma } \\
\text { Questionnaire }\end{array}$ & $\begin{array}{l}\text { homeopathy + } \\
\text { conventional }\end{array}$ & $\begin{array}{l}\text { placebo+ } \\
\text { conventional }\end{array}$ & $\begin{array}{l}\text { No statistically significant } \\
\text { changes in QOL score, small } \\
\text { improvement in severity. NB: } \\
\text { very high initial QOL score }\end{array}$ \\
\hline $\begin{array}{l}\text { Witt et al } \\
{[66]} \\
\text { All conditions } \\
3,12,24 \text { months }\end{array}$ & 3981 & $\begin{array}{l}\text { Prospective } \\
\text { multicentre } \\
\text { cohort } \\
\text { QOL score }\end{array}$ & homeopathy & - & $\begin{array}{l}\text { Marked and sustained } \\
\text { improvement }\end{array}$ \\
\hline
\end{tabular}

A first group of studies compared QOL-scores before and after treatment; control is the same group before treatment. Improvements are statistically and clinically significant, all diagnoses merged. Some diagnoses were especially analyzed: asthma in children, headache, cancer, anxiety and depression 
after suspension of estrogenic treatment due to breast cancer, allergy, general problems, intestinal disorders, anxiety disorder, depression and skin problems. These are also the most common diagnoses in general practice.

A second group used an external control group, treated with conventional medicine. Results show that homeopathy is as efficient as conventional medicine in general practice. Respiratory problems, chronic NET problems and problems during pregnancy were considered.

A third group used QOL-score during a RCT. In vertigo, homeopathy was as efficient as conventional medicine, but in a study on asthma, initial QOL was so high, that no significant difference could be found after treatment.

Studies about treatment cost-efficiency are mostly requested by authorities. Here also a evidence level IIIa was obtained for all analysed aspects. The reason for this interest is multiple. The cost of the conventional medicine is more and more a problem for certain patients. The survival of social security systems is threatened by these enormous costs.

Available data (15 studies - 9.932 patients) show that reduction of the total costs is possible while maintaining global efficacy when using homeopathy. (Table 4)

Table 4. Cost-efficiency of homeopathic treatment

\begin{tabular}{|c|c|c|c|c|c|}
\hline Condition/Study & $\mathrm{N}$ & $\begin{array}{l}\text { Design Economic } \\
\text { Survey }\end{array}$ & Test group & Control group & Results \\
\hline $\begin{array}{l}\text { Becker-Witt, et al } \\
\text { [67] } \\
\text { Different } \\
\text { chronic } \\
\text { conditions }\end{array}$ & 493 & $\begin{array}{l}\text { Prospective, } \\
\text { comparative } \\
\text { cohort. }\end{array}$ & $\begin{array}{l}\text { homeopathy; } \\
\text { patients could } \\
\text { opt for } \\
\text { concomitant } \\
\text { conventional } \\
\text { therapy }\end{array}$ & $\begin{array}{l}\text { patients } \\
\text { could opt for } \\
\text { conventional } \\
\text { therapy }\end{array}$ & $\begin{array}{l}\text { Patients seeking homeopathic } \\
\text { treatment had a better } \\
\text { outcome overall compared to } \\
\text { patients on conventional } \\
\text { treatment. }\end{array}$ \\
\hline $\begin{array}{l}\text { Chaufferrin } \\
{[68]}\end{array}$ & & $\begin{array}{l}\text { Compilation of } \\
\text { nationally } \\
\text { available data } \\
\text { (secondary } \\
\text { sources) }\end{array}$ & homeopathy & - & $\begin{array}{l}\text { Homeopathic medication } \\
\text { prices per unit lower than } \\
\text { allopathic (number of } \\
\text { prescriptions unknown, } \\
\text { though). Fewer } \\
\text { reimbursements for } \\
\text { homeopathic doctors, only } 1 \\
\text { \% of reimbursement of } \\
\text { French national health } \\
\text { insurance system }\end{array}$ \\
\hline $\begin{array}{l}\text { Frei et al } \\
{[69]} \\
\text { Acute otitis } \\
\text { media }\end{array}$ & 230 & $\begin{array}{l}\text { Prospective, } \\
\text { uncontrolled } \\
\text { interventional }\end{array}$ & homeopathy & - & $\begin{array}{l}72 \% \text { resolved within } 12 \\
\text { hours, } 28 \% \text { were given } \\
\text { antibiotics. Conventional } \\
\text { treatment was } 14 \% \text { more } \\
\text { expensive (109 SFR vs. } 94,6 \\
\text { SFR) }\end{array}$ \\
\hline $\begin{array}{l}\text { Frenkel et al } \\
{[70]} \\
\text { Atopic and } \\
\text { allergic } \\
\text { disorders }\end{array}$ & 48 & $\begin{array}{l}\text { Prospective, } \\
\text { uncontrolled } \\
\text { interventional }\end{array}$ & $\begin{array}{l}\text { homeopathy } \\
\text { primarily }+ \\
\text { conventional } \\
\text { treatment }\end{array}$ & - & $\begin{array}{l}\text { Before intervention on } \\
\text { average } 3.1 \text { different } \\
\text { conventional drugs/patient } \\
\text { after } 1.6(\mathrm{p}=0.001) \text {. Before } \\
\text { intervention } 31 \text { used } \\
\text { conventional drugs (costs on } \\
\text { average } \$ 40 \text { ) after } \\
\text { intervention } 35 \text { (costs on } \\
\text { average } \$ 16) \text {. }\end{array}$ \\
\hline $\begin{array}{l}\text { Güthlin et al } \\
\text { [53] } \\
\text { Different } \\
\text { chronic }\end{array}$ & 750 & $\begin{array}{l}\text { Prospective, } \\
\text { uncontrolled } \\
\text { observational }\end{array}$ & homeopathy & - & $\begin{array}{l}\text { Significant changes in quality } \\
\text { of life, less sick leave. }\end{array}$ \\
\hline
\end{tabular}




\begin{tabular}{|c|c|c|c|c|c|}
\hline conditions & & & & & \\
\hline $\begin{array}{l}\text { Van Haselen et al } \\
{[71]} \\
\text { Rheumatoid } \\
\text { arthritis }\end{array}$ & \begin{tabular}{|l|}
89 \\
(random \\
sample \\
out of \\
$427)$ \\
\end{tabular} & Retrospective & $\begin{array}{l}\text { homeopathy } \\
(\mathrm{n}=89) \\
\text { acupuncture } \\
(\mathrm{n}=4)\end{array}$ & - & $\begin{array}{l}32 \% \text { reduced conventional } \\
\text { drugs. Total costs for } 89 \\
\text { patients was } 7,129 \text { GBP } \\
\text { (including medication, staff } \\
\text { time and diagnostic } \\
\text { procedures - } 29 \% \text { of costs for } \\
\text { consultation, } 22 \% \text { for } \\
\text { conventional drugs ) }\end{array}$ \\
\hline $\begin{array}{l}\text { Jain } \\
{[72]} \\
\text { Reduced costs by } \\
\text { homeopathic } \\
\text { prescription }\end{array}$ & 109 & \begin{tabular}{|l|} 
Prospective \\
uncontrolled \\
observational
\end{tabular} & homeopathy & - & $\begin{array}{l}\text { Savings by homeopathic } \\
\text { treatment calculated by } \\
\text { deducting costs for } \\
\text { homeopathic medication from } \\
\text { conventional medication } \\
\text { (hypothetical) for same } \\
\text { diagnosis and same duration } \\
\text { amounted to } 60.40 \text { Pound } \\
\text { Sterling }\end{array}$ \\
\hline $\begin{array}{l}\text { Rossi et al } \\
{[73]} \\
\text { Respiratory } \\
\text { diseases }\end{array}$ & 99 & $\begin{array}{l}\text { Retrospective } \\
\text { observational }\end{array}$ & homeopathy & conventional & $\begin{array}{l}\text { Reduction in use of } \\
\text { conventional remedies, } 40 \% \\
\text { costs saved }\end{array}$ \\
\hline $\begin{array}{l}\text { Schafer et al } \\
{[74]} \\
\text { Allergic disorders }\end{array}$ & & $\begin{array}{l}\text { Population- } \\
\text { based nested } \\
\text { case control }\end{array}$ & $\begin{array}{l}\text { alternative } \\
\text { medicine }\end{array}$ & \begin{tabular}{|l|} 
no \\
alternative \\
medicine
\end{tabular} & $\begin{array}{l}26.5 \% \text { used CAM - patients } \\
\text { were significantly younger } \\
\text { and better educated. CAM } \\
\text { mostly provided by MDs, } \\
\text { average costs for single and } \\
\text { entire treatment of } 4 \text { and } 205 \\
\text { euro. CAM users scored } \\
\text { efficacy of conventional } \\
\text { therapy lower than non user } \\
(p<0.001)\end{array}$ \\
\hline $\begin{array}{l}\text { Sevar } \\
{[75]} \\
\text { All conditions }\end{array}$ & 455 & $\begin{array}{l}\text { Prospective } \\
\text { cohort }\end{array}$ & homeopathy & - & $\begin{array}{l}\text { Conventional drug saving of } \\
£ 39.90 / \text { patient/year }\end{array}$ \\
\hline $\begin{array}{l}\text { Taïeb et al } \\
\text { [76] } \\
\text { Chronic allergic } \\
\text { rhinitis }\end{array}$ & 300 & $\begin{array}{l}\text { Prospective, } \\
\text { comparative } \\
\text { cohort }\end{array}$ & $\begin{array}{l}\text { homeopathy } \\
\text { (H) }\end{array}$ & $\begin{array}{l}\text { conventional } \\
\text { (C) }\end{array}$ & $\begin{array}{l}\text { At } 3 \text { months SF-12 score on } \\
\text { physical dimension } \mathrm{H} 51.8 \text {; C } \\
47.9 \text { (p<0.05). Lowering of } \\
\text { cost of care for patients from } \\
45.74 € \text { for C to } 27 € \text { for } \mathrm{H} \text {; for } \\
\text { social security system } 50 \% \text { for } \\
\text { patients using H. }\end{array}$ \\
\hline $\begin{array}{l}\text { Trichard et al } \\
{[77]} \\
\text { Anxiety disorders }\end{array}$ & 394 & $\begin{array}{l}\text { Prospective, } \\
\text { comparative } \\
\text { cohort }\end{array}$ & homeopathy & conventional & $\begin{array}{l}\text { Homeopathy produced } \\
\text { equivalent result but less } \\
\text { overall costs reimbursed by } \\
\text { national health system }\end{array}$ \\
\hline $\begin{array}{l}\text { Trichard et al } \\
\text { [78] } \\
\text { Acute } \\
\text { rhinopharyngitis }\end{array}$ & 499 & $\begin{array}{l}\text { Prospective, } \\
\text { comparative } \\
\text { cohort }\end{array}$ & homeopathy & \begin{tabular}{|l} 
conventional \\
(antibiotics)
\end{tabular} & $\begin{array}{l}\text { Comparable overall costs, but } \\
\text { less sick leave in the } \\
\text { homeopathic group }\end{array}$ \\
\hline $\begin{array}{l}\text { Trichard et al } \\
\text { [79] }\end{array}$ & 5,549 & $\begin{array}{l}\text { Cross-sectional } \\
\text { descriptive } \\
\text { survey }\end{array}$ & homeopathy & - & $\begin{array}{l}\text { Only costs for medication } \\
\text { included - average overall } \\
\text { cost } 6.78 € \text { of which } 3.78 € \\
\text { were reimbursed }\end{array}$ \\
\hline Wassenhoven et & \begin{tabular}{|l|}
782 \\
\end{tabular} & $\begin{array}{l}\text { Observational } \\
\text { unselected; }\end{array}$ & homeopathy & - & $\begin{array}{l}\begin{array}{l}\text { Following homeopathic } \\
\text { treatment, significant }\end{array} \\
\end{array}$ \\
\hline
\end{tabular}




\begin{tabular}{|c|c|c|c|c|c|}
\hline $\begin{array}{l}\text { al }[80] \\
\text { All conditions }\end{array}$ & & $\begin{array}{l}\text { comparison to } \\
\text { nationally } \\
\text { available data } \\
\text { (secondary } \\
\text { sources) }\end{array}$ & & & $\begin{array}{l}\text { reduction in consultations to } \\
\text { other specialists and } \\
\text { generalists; cost of treatment } \\
€ 370 \text { to } € 287 \text {. The largest cost } \\
\text { savings made by the patients } \\
\text { with the worst ratings of } \\
\text { their physical condition prior } \\
\text { to homeopathic treatment }\end{array}$ \\
\hline $\begin{array}{l}\text { Witt et al } \\
{[81]} \\
\text { Atopic eczema }\end{array}$ & 135 & $\begin{array}{l}\text { Prospective, } \\
\text { comparative } \\
\text { cohort }\end{array}$ & homeopathy & conventional & $\begin{array}{l}\text { Comparable efficacy, less } \\
\text { costs in homeopathic group }\end{array}$ \\
\hline
\end{tabular}

Once again, a first group of studies compares the same cohort of patients before and after the study. The control group is the group itself before treatment. Financial savings with homeopathy are statistically and clinically significant for all diagnoses merged. Some diagnoses are especially analyzed, such as otitis media, atopic eczema and allergy, rheumatoid arthritis and anxiety disorders.

A second group uses an external control group using conventional treatment. The results of these studies confirm that homeopathic treatment in general practice allows savings under all conditions. Some data were especially analyzed, such as seasonal allergic rhinitis, asthma, atopic eczema, food related allergy, chronic allergic rhinitis, anxiety disorders and acute rhinopharyngitis.

\section{Internal Evidence Heuristic}

Homeopathy acts following the principle of similarity: symptoms are treated with a medicine able to cause similar symptoms in a healthy person. This principle must be observed in clinical and basic studies.

\section{Pure experiments or 'provings'}

In order to know the effects of homeopathic medicines, experiments are conducted on healthy individuals. This procedure was initiated by $\mathrm{S}$. Hahnemann more than two centuries ago and has never stopped since. In our days, provings are standardized and performed as a rule with a placebo control [82].

Therefore, the homeopathic materia medica has some level of evidence, and the higher the level of evidence, the higher the probability that the remedy will heal the patient. On the other hand, the more "significant" symptoms the patient has in common with the medicine, the more remarkable and complete will be the effect of the latter. The analysis of published provings indicates evidence level IIb [83].
At the 63rd World Congress of LMHI, 2008, a number of provings was presented. Provings, methods and results are described in Table 5.

\section{Clinical verification of homeopathic symptoms}

Symptoms obtained through pure experimentation must be confirmed by clinical results. Traditionally, experts in homeopathy were considered references for clinical verification? This corresponds to evidence level IV. Expert advice is very common in medicine. The "ideal value" of cholesterol, e.g. corresponds to this same level of evidence.

Two statistical techniques may be applied to retrospective analysis:

1- To consider exclusively indisputable results of homeopathic prescriptions, i.e. failures or spectacularly positive results. Analysis involves searching for a possible link between outcome and the symptoms of the patient selected for the choice of the remedy. This method is very close to the traditional analysis by experts. Results establish a strong connection between the results of pure experimentation and clinical efficacy of the prescription [95]. At the end of the process, a table of characteristic symptoms (or groups of symptoms) composing the characteristic picture of the homeopathic medicine may be established and verified [96].

2- To apply Bayes' theorem to the same clinical database. All values are expressed as prevalence and compared to the remainder of the population (Likelihood ratio or probability factor as the link between a medicine's symptom and the observed clinical results). This method may be applied in both retrospective [69] and prospective [70] designs.

These statistical treatments allow to attain evidence level IIIb. Clinical verification of homeopathic symptoms represents internal validation of the principles of homeopathy and its results will be able to be used to improve daily practice in the near future. A description of the 
latest reports on clinical verification is presented in

Table 6.

Table 5. Provings presented at $63^{\text {rd }}$ World Congress of LMHI

\begin{tabular}{|l|l|l|}
\hline Remedy & Design & Results \\
\hline $\begin{array}{l}\text { Hydrogenium peroxidatum } \\
\text { [84] }\end{array}$ & $\begin{array}{l}\text { Double-blind, randomized, } \\
\text { controlled }\end{array}$ & $\begin{array}{l}16 \text { provers presented several symptoms } \\
\text { clinically verified in humans and animals. }\end{array}$ \\
\hline $\begin{array}{l}\text { Lactrodectus mactans } \\
\text { tredecimguttatus [85] }\end{array}$ & Open & $\begin{array}{l}8 \text { provers manifested groups of symptoms } \\
\text { clinically verifies }\end{array}$ \\
\hline Potentilla anserine [86] & $\begin{array}{l}\text { Multi-centric, prospective, } \\
\text { double blind. }\end{array}$ & $\begin{array}{l}10 \text { provers manifested 27 groups of } \\
\text { symptoms }\end{array}$ \\
\hline Neptunium muriaticum [87] & Placebo-controlled & $\begin{array}{l}19 \text { provers manifested 315 symptoms } \\
\text { distributed into 12 groups. }\end{array}$ \\
\hline Helleborus niger [88] & $\begin{array}{l}\text { Third confirmation, multi- } \\
\text { centric, international. }\end{array}$ & 4 groups of symptoms are regularly recorded. \\
\hline Sutherlandia frutescens [89] & $\begin{array}{l}\text { Double-blind, } \\
\text { controlled. }\end{array}$ & $\begin{array}{l}24 \text { provers manifested 15 symptoms } \\
\text { correlated to the traditional use of the pant. }\end{array}$ \\
\hline Eryhtrina lysistemon [90] & $\begin{array}{l}\text { Triple-blind, } \\
\text { controlled. }\end{array}$ & 32 provers manifested 25 symptoms. \\
\hline Lobelia cardinalis [91] & Open design & 7 provers revealed 32 symptoms \\
\hline Gallium aparine [92] & Open design & 8 provers manifested 18 groups of symptoms \\
\hline Ytterbium nitricum [93] & Open design & 13 provers manifested 32 symptoms \\
\hline Hecla lava [94] & Multi-centric, international & \\
\hline
\end{tabular}

Table 6. Latest reports on clinical verification of homeopathic symptoms

\begin{tabular}{|c|c|c|c|c|c|}
\hline Study & $\begin{array}{l}\text { Number } \\
\text { subjects }\end{array}$ & Design & $\begin{array}{l}\text { Number } \\
\text { symptoms }\end{array}$ & $\begin{array}{l}\text { Number } \\
\text { remedies }\end{array}$ & Results \\
\hline $\begin{array}{l}\text { Van } \\
\text { Wassenhoven } \\
\text { [95] }\end{array}$ & 2148 & LR R & $>230$ & 100 & $\begin{array}{l}\text { Symptoms; } \\
\text { similarity; } \\
\text { globality }\end{array}$ \\
\hline CCRH [96] & 3032 & TM & $?$ & 1 & Symptoms \\
\hline Rutten et al [99] & 4094 & LR P & 6 & 75 & Similarity \\
\hline Araújo [100] & 5 & TM & $?$ & 1 & $\begin{array}{l}16 \text { groups of } \\
\text { symptoms; } \\
\text { Similarity } \\
\text { (constitution) }\end{array}$ \\
\hline $\begin{array}{l}\text { Gnaiger et al } \\
\text { [101] }\end{array}$ & 25 & TM & $?$ & 1 & $\begin{array}{l}6 \text { groups of } \\
\text { symptoms; } \\
\text { Similarity }\end{array}$ \\
\hline Dominici [84] & 18 & TM & 10 & 1 & $\begin{array}{l}\text { Proving } \\
\text { symptoms; } \\
\text { Similarity }\end{array}$ \\
\hline AFADH [85] & 5 & TM & ? & 1 & $\begin{array}{l}36 \text { groups of } \\
\text { symptoms; } \\
\text { Similarity } \\
\text { (constitution) }\end{array}$ \\
\hline Louis [102] & 12 & TM & $?$ & 1 & 6 groups of \\
\hline
\end{tabular}




\begin{tabular}{|c|c|c|c|c|c|}
\hline & & & & & $\begin{array}{l}\text { symptoms; } \\
\text { Similarity } \\
\text { (constitution) }\end{array}$ \\
\hline Lustig [89] & 2 & TM & $?$ & 1 & $\begin{array}{l}1 \quad \text { group of } \\
\text { symptoms; } \\
\text { Similarity } \\
\text { (constitution) }\end{array}$ \\
\hline Marim et al [88] & 5 & TM & ? & 4 & $\begin{array}{l}5 \quad \text { groups of } \\
\text { symptoms; } \\
\text { Similarity } \\
\text { (constitution) }\end{array}$ \\
\hline Petrucci [103] & 8 & TM & 8 & 1 & $\begin{array}{l}\text { Proving } \\
\text { symptoms; } \\
\text { Similarity }\end{array}$ \\
\hline Pla [104] & 2 & TM & 95 & 1 & $\begin{array}{l}7 \quad \text { groups of } \\
\text { symptoms; } \\
\text { Similarity } \\
\text { (constitution) }\end{array}$ \\
\hline $\begin{array}{lll}\begin{array}{l}\text { Servais } \\
{[105]}\end{array} & \text { et } & \text { al } \\
\end{array}$ & 11 & TM & 220 & 1 & Symptoms \\
\hline $\begin{array}{l}\text { Stolper et al } \\
{[106]}\end{array}$ & 26 & TM & 23 & 2 & $\begin{array}{l}\text { Proving } \\
\text { symptoms; } \\
\text { Similarity }\end{array}$ \\
\hline $\begin{array}{l}\text { Uyttenhove } \\
{[107]}\end{array}$ & 300 & TM & 6 & 1 & $\begin{array}{l}\text { Proving } \\
\text { symptoms; } \\
\text { Similarity }\end{array}$ \\
\hline $\begin{array}{l}\text { Uyttenhove } \\
{[107]}\end{array}$ & 262 & TM & $?$ & 1 & $\begin{array}{l}\text { Proving } \\
\text { symptoms; } \\
\text { Similarity }\end{array}$ \\
\hline
\end{tabular}

LR: Likelihood ratio R: retrospective P: prospective TM: traditional method

\section{Homeopathic Medicines have specific activity}

In the present time, the proof for the action of high dilutions has reached evidence level IIa, in some instances, level I. Several university-based researchers had surveyed literature on this subject, upon European Committee for Homeopathy request [108]. New references are added for 2005-2008.

The least expensive model, easy to perform and to reproduce, probably is "acetylcholine-induced contraction of rat ileum". This is a validated experimental model [109], initially applied to homeopathic preparations by Cristea [110]. SüB, from the Institute of Pharmacy of Leipzig university used this model to test the transition of homeopathic Atropinum sulphuricum 60D from the original liquid form to tablets [111]. Monohydrate alactose tablets impregnated with high dilution of Atropinum showed systematic efficacy as opposed to anhydrous a-lactose tablets. This means that the quality of tablets can be tested before pharmaceutical commercialization (constant reproducibility). This simple model shows beyond any doubt that high diluted homeopathic medicines are active.
It took some time before another experimental model could be accepted by the scientific community. Initial development was in 1991, but only in 2004 results were accepted for publication by Inflammation Research, a peer-reviewed scientific journal [112]. Roberfroid and Cumps, from the Department of Pharmacy of Louvain university, led a multi-centric European survey involving 4 laboratories, showing the clear inhibition of human basophils degranulation by high dilutions of histamine [113,114].

There is research in high dilutions since the $1950 \mathrm{~s}$, but the number and quality of publications has increased in the last decade. Articles showing the efficacy of high dilutions were published in peerreviewed journals [115-117] as well as their efficacy on pharmacological models [118-127].

The oldest model used, subject of several international publications is the toxicological (arsenic, phosphor, mercury, cadmium, cisplatin, glutamate, sulphate, copper sulphate, etc.) This model is still in use and is currently the subject of cooperative research between the universities of Bern and Bologna on the effect of homeopathic preparations of arsenic trioxide in plants. This research group, under the coordination of Dr. 
Lucietta Betti, has recently published the results of some experiments [128-132].

A systematic review of in vitro evidence for high dilutions has been published in 2007 [133]. Conclusions state that experiments with high methodological standards were able to demonstrate effects. No positive result was as stable as to be reproduced by all researchers; among those that were replicated by independent researchers: the effect of mercury bichloride on hydrolases and, especially, of histamine on basophils degranulation, as mentioned above.

Several audits of these publications are available and justify evidence level I [133, 135, 136]. 75 publications were evaluated by a German team, 105 articles were analyzed in a second audit examining the protective effect against toxics (isopathic model). $70 \%$ of the articles are of indisputable quality and show the positive effect of the homeopathic preparations employed. In a third audit, 76 of the 162 analyzed studies were rated as "highest quality", effects are significant and reproducible.

New results, since 2005, include Alecu et al. [136,137], dos Santos et al. [138] and those presented at $63^{\text {rd }}$ World Congress of LMHI, 2008 $[139,140]$.

\section{Homeopathy in veterinary parctice}

Advantages of the results of veterinary practice are several: environment where animals live may be considered stable and very similar for all animals considered; studies on large animal cohorts are easier to conduct than in humans; double-blind designs are easier to achieve.
The number of surveys is still small, but for two clinical diagnoses sufficient studies have been published and reproduced, so that evidence level I might be attained in the near future. These two areas are infertility in cows [141-143] and mastitis in cows $[144,145]$. Both problems have important consequences for public health as antibiotics (usually prescribed for mastitis) enter the food chain and milk, therefore, must be destroyed, with the corresponding economic consequences. Moreover, homeopathic treatment is the only one authorized in Europe in organic breeding.

Other results come from another farming area: chickens are very sensitive to stress, and pick each other, which results in important production losses [146]. The same is observed in turkeys, very sensitive to hematomas caused during transportation. This problem can be reduced 30\% with homeopathic treatment. Regulation of sexual hormones in sows is also significant [147], homeopathy can offer a solution without risks for consumers.

More recent works have been reported between 2006-2008 [148-162].

\section{Individualized homeopathic research}

When the individualizing approach of homeopathy is taken into account, the scientific framework is much broader than the expected. Homeopathic physicians are mostly focused on research on individualization, similarity and globality. This does not exclude research centered on specific diagnostic categories, and many indications are reaching evidence level IIIb. A few examples presented at 63 ${ }^{\text {rd }}$ World Congress of LMHI, 2008 are described in Table 7.

Table 7. Clinical research on specific diagnostic categories, LMHI, 2008.

\begin{tabular}{|l|l|l|}
\hline Area & Diagnostic category & Studies \\
\hline Allergy & Asthma & $\begin{array}{l}\text { Flitchev et al.[163]; Kekata et } \\
\text { al.[164] }\end{array}$ \\
\hline & Atopic dermatitis & Jurj [165]; Popowski[166] \\
\hline Dentistry & Summer benign lucitis & Marijnen et al.[167] \\
\hline & Extraction of third molar & Camacho et al.[168] \\
\hline & Periodontal disease & Clercq et al.[169] \\
\hline Gynecology & Temporomandibular disorders & Tiba et al.[170] \\
\hline & Cervical dystocia & Chiche[171] \\
\hline & Flushes & Dungler et al.[172]; Masson et \\
\hline
\end{tabular}




\begin{tabular}{|c|c|c|}
\hline & & al.[173] \\
\hline & Recurrent vaginal mycoses & Honneger et al.[174] \\
\hline & Prolactinoma & Roca [175] \\
\hline & Uterine fibroid and ovarian cyst & Shangloo [176] \\
\hline & Breast lumps & Shukla [177] \\
\hline \multirow[t]{2}{*}{ Endocrinology } & Hypothyroidism & Grelle [178] \\
\hline & Chronic thyroiditis & Baroli [179] \\
\hline \multirow[t]{4}{*}{ Infectious diseases } & Bronchiolitis & Arjoun et al. [180] \\
\hline & Chickenpox & Bahloul et al. [181] \\
\hline & Eye irritation & Fayard [182] \\
\hline & Long lasting fever of febrile origin & Rusev et al. [183] \\
\hline \multirow[t]{9}{*}{ Neurology } & Muscular dystrophy & Bolognani et al.[184] \\
\hline & Progressive spinal amiotrophy & Bolognani et al. [185] \\
\hline & $\begin{array}{l}\text { Attention deficit hyperactivity } \\
\text { disorder }\end{array}$ & $\begin{array}{l}\text { Bolognani et al. [186]; Mateescu } \\
\text { [187] }\end{array}$ \\
\hline & Infantile cerebral palsy & $\begin{array}{l}\text { Damaceno et al. [188]; Serpa et } \\
\text { al.[189] }\end{array}$ \\
\hline & Migraine & Kivellos et al.[190] \\
\hline & Choreoathetosis & Martins et al.[191] \\
\hline & Parkinson's disease & Mendes et al.[192] \\
\hline & Spastic conditions & Teixeira et al.[193] \\
\hline & Multiple sclerosis & Roberfroid et al.[194] \\
\hline Oncology & Veterinary & Pevenage [195] \\
\hline Toxicology & Arsenic poisoning & Khuda-Bukhsh [196] \\
\hline
\end{tabular}

\section{Conclusions}

Consideration of patients' rights means that patients must be informed of all possible therapies that may improve his/her health, including homeopathy, even when hospitalized.

The evidence level of homeopathy in several conditions is sufficient to ground its use in the scientific framework of general medical practice. Basic and veterinary research confirm findings in humans. Internal evidence validated and confirms the effects of homeopathic medicines.

University research on homeopathy must be encouraged and supported by public health authorities.

Data presented in this review are indisputable. For this reason, homeopathy must be accepted within the scientific framework of medicine, especially in general medical practice. 


\section{References}

[1] Zhang X. National policy on Traditional Medicine and regulation of Herbal Medicines. Report of a WHO global survey. Geneve: WHO; 2005.

[2] CAM-CANCER project funded by the European Commission within the $5^{\text {th }}$ Framework Programme "Quality of Life". How are European patients safeguarded when using complementary and alternative medicine? Jurisdictions, supervision and reimbursement status in the EEA area (Eu and EFTA) and Switzerland. Tromsø: Complementary and Alternative Medicine Assessment in the Cancer Field; 2005-[updated 2005 Oct 28; cited 2008 May]. Available from: http://www.cam-cancer.org/CAMand-the-law/Introduction/Preface.

[3] Consortium of Academic Health Centers for Integrative Medicine. Minneapolis: CAHCIM [updated 2008 Nov 07; cited 2008 May]. Available from: http://www.imconsortium.org.

[4] Oberbaum M, Singer SR, Friehs H, Frass M. Homeopathy in emergency medicine. Wien Med Wochenschr. 2005; 155: 491-497.

[5] Frass M, Linkesch M, Banyai S, Resch G, Dielacher C, Löbl T, et al. Adjunctive homeopathic treatment in patients with severe sepsis: a randomized, double blind, placebo-controlled trial in a intensive care unit. Homeopathy. 2005; 94: 75-80.

[6] Frass M, Dielacher RN, Linkesch MD, Endler C, Muchitsch I, Schuster E, et al. Influence of potassium dichromate on tracheal secretions in critically ill patients. Chest. 2005; 127: 936-941.

[7] Marques Arpa A. Arnica in sepsis: Clinical cases at the Intensive Care Unit with complementary homeopathic treatment [CD-Rom]. Oostende: GIRI; 2008.

[8] Kleijnen J, Knipschild P, ter Riet G. Clinical trials of homeopathy. BMJ. 1991; 302: 316-323.

[9] Boissel JP, Cucherat M, Haugh M, Gauthier E. Critical literature review on the effectiveness of homoeopathy: overview of data from homoeopathic medicine trials. In: Report to the European Commission. Brussels: Homoeopathic Medicine Research Group; 1996. 195-210.

[10] Linde K, Clausius N, Ramirez G, Melchart D, Eitel F, Hedges LV, et al. Are the clinical effects of homeopathy placebo effects? A meta-analysis of placebo-controlled trials. Lancet. 1997; 350(9081): 834-843.

[11] Linde K, Melchart D. Randomized controlled trials of individualized homeopathy: a state-of-the art review. J Alter Complement Med. 1998; 4: 371388.
[12] Cucherat M, Haugh MC, Gooch M, Boissel JP. Evidence of clinical efficacy of homeopathy. A metaanalysis of clinical trials. Eur J Clin Pharmacol. 2000; 56: 27-33.

[13] Shang A, Huwiler-Müntener K, Nartey L, Jüni P, Dörig S, Sterne JAC, et al. Are the clinical effects of homeopathy placebo effects? Comparative study of placebo-controlled trials of homeopathy and allopathy. Lancet. 2005; 366: 726-732

[14] GRECHO (Groupe de Recherche et d'Essais Cliniques en Homéopathie). Evaluation de deux produits homéopathiques sur la reprise du transit après chirurgie digestive : un essai contrôlé multicentrique. Presse Med, 1989; 18: 59-62

[15] Jonas WB, Kaptchuk TJ, Linde K. A critical overview of homeopathy. Ann Intern Med. 2003; 138: 393-399

[16] Lüdtke R, Wiesenauer M. A meta-analysis of homeopathic treatment of pollinosis with Galphimia glauca. Wien Med Wochenschr. 1997; 147: 323-327.

[17] Barnes J, Resch K-L, Ernst E. Homeopathy for postoperative ileus? A meta-analysis. J Clin Gastroenterol, 1997; 25: 628-633.

[18] Jonas WB, Linde K, Ramirez G. Homeopathy and rheumatic disease. Rheum Dis Clin North Am. 2000; 26: 117-123.

[19] Szeta AL, Rollwagen F, Jonas WB. Rapid induction of protective tolerance to potential terrorist agents: a systematic review of low- and ultra-low dose research. Homeopathy. 2004; 93: 173178.

[20] Matusiewicz R. The effect of a homeopathic preparation on the clinical condition of patients with corticosteroid-dependent bronchial asthma. Biomed Ther. 1997; 15: 70-74.

[21] Fisher P. An experimental double-blind clinical trial method in homeopathy. Use of a limited range of remedies to treat fibrositis. Br Homeopath $\mathrm{J}$. 1986; 75: 142-147.

[22] Fisher P, Greenwood A, Huskinsson EC, Turner P, Belon P. Effect of homeopathic treatment on fibrositis (primary fibromyalgia). Br Med J. 1989; 299: 365-366.

[23] Bell IR, Lewis II DA, Brooks AJ, Schwartz GE, Lewis SE, Walsh BT, et al. Improved clinical status in fibromyalgia patients treated with homeopathy versus placebo. Rheumatology. 2004; 43(5): 577-582.

[24] Ferley JP, Zmirou D, Adhemar D, Balduci F. A controlled evaluation of a homeopathic preparation in the treatment of influenza-like syndromes. $\mathrm{Br} \mathrm{J}$ Clin Pharmacol, 1989; 27: 329-335.

[25] Papp R, Schuback G, Beck E, Burjard G, Bengel J, Lehri S. Oscillococcinum in patients with influenza-like syndromes: a placebo-controlled 
double-blind evaluation. Br Homeopath J. 1998; 87: 69-76.

[26] Tveiten D, Bruseth S, Borchgrevink CF, Norseth J. Effects of the homeopathic remedy Arnica D30 on marathon runners: a randomized, double-blind study during the 1995 Oslo Marathon. Complement Ther Med. 1998; 6: 74-74.

[27] Hariveau E. La recherche clinique a l'institut Boiron. Homéopathie. 1987; 5: 55-58.

[28] Harrison H, Fixsen A, Vickers A. A randomized comparison of homoeopathic and standard care for the treatment of glue ear in children. Complement Ther Med. 1999; 7: 132-135.

[29] Jacobs J, Springer DA, Crothers D. Homeopathic treatment of acute otitis media in children: a preliminary randomized placebocontrolled trial. Pediatr Infect Dis J. 2001; 20: 177 183.

[30] Stam C, Bonnet MS, van Haselen RA. The efficacy and safety of a homeopathic gel in the treatment of acute low back pain: a multicentre, randomised, double-blind comparative clinical trial. Br Homeopath J. 2001; 90: 21-28.

[31] Ernst E, Saradeth T, Resch KL. Complementary treatment of varicose veins: a randomized, placebo-controlled, double-blind trial. Phlebology. 1990; 5: 1571-1563.

[32] Balzarini A, Felisi E, Martini A, De Conno F. Efficacy of homeopathic treatment of skin reactions during radiotherapy for breast cancer: a randomised, double-blind clinical trial. $\mathrm{Br}$ Homeopath J. 2000; 89: 8-12.

[33] Kulkarni A, Nagarkar BM, Burde GS. Radiation protection by use of homoeopathic medicines. Hahnemann Homoeopath Sand. 1998; 12: 20-23.

[34] Böhmer D, Ambrus P. Behandlung von Sportverletzungen mit Traumeel-Salbe: Kontrollierte Doppelblindstudie. Biol Med. 1992; 21: 260-368.

[35] Zell J, Connert WD, Mau J, Feuerstake C. Treatment of acute sprains of the ankle joint: double-blind study assessing the effectiveness of a homeopathic ointment preparation. Fortschr Med. 1988; 106: 96-100.

[36] de Lange de Klerk ES, Blommers J, Kuik DJ, Bezemer PF, Feenstra L. Effect of homeopathic medicines on daily burden of symptoms in children with recurrent upper respiratory tract infections. $\mathrm{Br}$ Med J. 1994; 309: 1329-1332

[37] Weiser M, Clasen BPE. Controlled double-blind study of a homeopathic sinusitis medication. Biol Ther. 1995; 13: 4-11.
[38] McCutcheon LE. Treatment of anxiety with a homeopathic remedy. J Appl Nutr. 1996; 48: 2-6.

[39] Lamont J. Homeopathic treatment of attention deficit hyperactivity disorder: a controlled study. $\mathrm{Br}$ Homeopath J. 1997; 86: 196-200.

[40] Frei H, Everts R, von Ammon K, Kaufmann F, Walther D, Hsu Schmitz SF, et al. Randomised controlled trials of homeopathy in hyperactive children: treatment procedure leads to an unconventional study design. Homeopathy. 2007; 96: 35-41.

[41] Rahlfs VW, Mössinger P. Asa foetida in the treatment of the irritable colon: a double-blind trial. Dtsch Med Wochenschr. 1979; 104: 140-143.

[42] Brigo B, Serpelloni G. Homeopathic treatment of migraines: a randomized double-blind controlled study of sixty cases (homeopathic remedy versus placebo). Berlin J Res Homeopath. 1991; 1: 98-106.

[43] Van Haselen RA, Fisher PAG. A randomized controlled trial comparing topical piroxicam gel with a homeopathic gel in osteoarthritis of the knee. Rheumatology. 2000; 39: 714-719.

[44] Yakir M, Kreitler S, Brzezinski A, Vithoulkas G, Oberbaum M, Bentwich Z. Effect of homeopathic treatment in women with premenstrual syndrome: a pilot study. Br Homeopath J. 2001; 90: 148-153.

[45] Berrebi A, Parant O, Ferval F, Thene M, Ayoubi JM, Connan L, et al. Homeopathic treatment of pain associated with unwanted post partum lactation. J Gynecol Biol Reprod. 2001; 30: 353-357.

[46] Genre D, Tarpin C, Braud AC, Camerlo J, Protiere C, Eisinger F, et al. Randomized, doubleblind study comparing homeopathy (cocculine) to placebo in prevention of nausea/vomiting among patients receiving adjuvant chemotherapy for breast cancer. Breast Cancer Res Treat. 2003; 82(Supl 1). 637.

[47] Robertson A, Suryanarayanan R, Banerjee A. Homeopathic Arnica montana for post-tonsillectomy analgesia: a randomized placebo control trial. Homeopathy. 2007; 96: 17-21.

[48] Becker-Witt C, Lüdtke R, Willich SN. "Patienten in der homöopathischen Praxis"- In: Albrecht H, Frühwald M, editors. Jahrbuch 9, Karl und Veronica Carstens-Stiftung. Essen: KVC Verlag; 2003. 3-15.

[49] Becker-Witt C, Lüdtke R, Weber K, Willich SN. The effects of homoeopathic therapy on healthrelated quality of life. FACT. 2003. 8: 124.

[50] Bordet MF, Colas A, Marijnen P, Masson JL, Trichard M. Treating hot flushes in menopausal women with homeopathic treatment: results of an observational study. Homeopathy. 2008; 97: 10-15. 
[51] Dias Brunini CR. Qualidade de vida e abordagem homeopática em crianças asmáticas. Infanto. 2002; 10(1): 18-21.

[52] Goossens M, Laekeman G, Aertgeerts B, Buntinx F. Evaluation of the Quality of Life after individualized homeopathic treatment for seasonal allergic rhinitis. A prospective, open, noncomparative study [CD-Rom]. Oostende: GIRI;2008.

[53] Guthlin C, Walach H. Prospecktive Dokumentationstudie in der nierdergelassenen Praxis: ein Erprobungsverfahren zur Akupunktur und Homoopathie. Erfahrungsheilkunde. 2001 Apr; 50(4): 186-194.

[54] Guthlin C, Walach $H$. The challenge of assessing the effects of homeopathy in real life practice. Proceedings of the Improving the Success of Homeopathy. 2003 Apr 4-5; London, United Kingdom. London: Royal Homoeopathic Hospital; 2003. 50-56.

[55] Jong MC, Riley D, Haidvogl M. International integrative primary care outcomes study (IIPCOS-

2): homeopathic and conventional treatment for acute respiratory and ear complaints. Proceedings of the Improving the Success of Homeopathy. 2006 Jan 26-27: London, United Kingdom. London: Royal Homoeopathic Hospital; 2006. 35-42.

[56] Riley D, Fischer M, Singh B, Haidvogl M, Heger M. Homeopathy and conventional medicine: an outcomes study comparing effectiveness in a primary care setting. J Alternative Compl Med. 2001; 7(2): 149-159.

[57] Hochstrasser B. Lebensqualität von schwangeren Frauen in Abhängigheit von einer homöopathischen oder schulmeizinischen Betreuungsform und vom Schangerschaftsverlauf. Forsch Komplementarmed. 1999 ; 6( Suppl 1): 23-25.

[58] Muscarini R, Kemmler G, Schweigkofler H, Holzner B, Dunser M, Richter R, et al. Observational study of quality of life in patients with headache, receiving homeopathic treatment. $\mathrm{Br}$ Homeopath J. 2001 ; 90(4): 189-197.

[59] Spence D, Thompson EA, Barron SJ. Homeopathic treatment for chronic disease: a 6year, university-hospital outpatient observational study. J Alternative Compl Med. 2005; 11 (5): 793798.

[60] Strosser W, Weiser M, Lebensqualität bei Patienten mit Schwindel: Homöopathikum im Doppelblind-Vergleich. Biol Medizin. 2000; 29(5): 242-247.

[61] Thompson EA, Reilly D. The homeopathic approach to symptom control in the cancer patient. Palliative Medicine. 2002; 16(3): 227-233.

[62] Thompson EA, Reilly D. The homeopathic approach to the treatment of symptoms of oestrogen withdrawal in breast cancer patients. Homeopathy. 2003; 92(3): 131-134.

[63] Anelli M, Scheepers L, Sermeus G, van Wassenhoven M. Homeopathy and health related quality of life: a survey in six European countries. Homeopathy. 2002; 91(1): 18-21.

[64] Weber U, Lüdtke R, Friese KH, Fischer I, Moeller H. A non-randomised pilot study to compare complementary and conventional treatments of acute sinusitis. Forschende Komplementarmedizin und Klassische Naturheilkunde. 2002; 9(2): 99-104.

[65] White A, Slade P, Hunt C, Hart A, Ernst E. Individualised homeopathy as an adjunct in the treatment of childhood asthma. Thorax. 2003; 58(4): 317-321.

[66] Witt CM, Luedtke R, Baur R, Willich SN. Homeopathic medical practice: long-term results of a cohort study with 3981 patients. BMC Public Health. 2005; 5: 115.

[67] Becker-Witt C, Keil T, Roll S, Mencke D, Vance W, Wegscheider K, et al. Effectiveness and costs of Homeopathy compared to conventional medicine: a prospective multicenter cohort study. Proceedings of Bridging the Credibility Gap. Conference Report. 2003 Apr; London, United Kingdom. London: The London Homoeopathic Hospital; 2003. 57-60.

[68] Chaufferin G. Improving the evaluation of homeopathy: economic considerations and impact on health. Br Homeopath J. 2000; 89(Suppl 1): S27-30.

[69] Frei H, Thurneysen A. Homeopathy in acute otitis media in children: treatment effect or spontaneous resolution? Br Homeopath J. 2001; 90(4): 180-182.

[70] Frenkel M, Hermoni D. Effects of homeopathic intervention on medication consumption in atopic and allergic disorders. Altern Ther Health Med. 2002; 8(1): 76-79.

[71] Van Haselen RA, Graves N, Dahiha S. The costs of treating rheumatoid arthritis patients with complementary medicine: exploring the issue. Complement Ther Med. 1999; 7(4): 217-221.

[72] Jain A. Does homeopathy reduce the cost of conventional drug prescribing? A study of comparative prescribing costs in general practice. Homeopathy. 2003; 92(2): 71-76.

[73] Rossi E, Crudeli L, Endrizzi C, Garibaldi D. Cost-effectiveness evaluation of homeopathic vs conventional therapy in respiratory diseases. Proceedings of Improving the Success of Homeopathy; 2006 Jan 26-27; London: United Kingdom. London: The London Homoeopathic Hospital; 2006. 5.

[74] Schafer T, Riehle A, Wichmann HE, Ring J. Alternative medicine in allergies: prevalence, 
patterns of use, and costs. Allergy. 2002; 57(8): 694700 .

[75] Sevar R. Audit of outcome in 455 consecutive patients treated with homeopathic medicines. Homeopathy. 2005; 94: 215-221.

[76] Taïeb C, Myon E. Chronic allergic rhinitis, usefulness of the homeopathic treatment. International Society of Pharmacoeconomics \& Outcomes Research. Proceedings of $8^{\text {th }}$ Annual International Meeting; 2003 May 18-21; Arlington, United States. New Jersey, International Society for Pharmacoeconomics and Outcomes Research; 2003. 37-48.

[77] Trichard M, Chaufferrin G. Effectiveness, quality of life and cost of caring for children in France with recurrent acute rhinopharyngitis managed by homeopathic or non-homeopathic general practitioners. Dis Manage Health Outcomes. 2004; 12(6): 419-427.

[78] Trichard M, Chaufferrin G. Cost-effectiveness study of treatment of anxiety disorders by homeopathic general practitioners. Proceedings of the Improving the Success of Homeopathy. 2003; London, United Kingdom. London, The Royal Homoeopathic Hospital; 2003. 71-72.

[79] Trichard M, Lamure E, Chaufferrin G. Study of the practice of homeopathic general practitioners in France. Homeopathy. 2003; 92(3): 135-139.

[80] Van Wassenhoven M, Ives G. An observational study of patients receiving homeopathic treatment. Homeopathy. 2004; 93: 3-11.

[81] Witt C. Effectiveness of homeopathy, an example of systematic research in children with atopic eczema [CD-Rom]. Oostende: $63^{\text {rd }}$ Congress of LMHI; 2008.

[82] Dominici G, Bellavite P, di Stanislao C, Gulia P, Pitari G. Double-blind, placebo-controlled homeopathic pathogenetic trials: Symptom collection and analysis. Homeopathy. 2006; 95: 123130 .

[83]Walach H, Sherr J, Schneider R, Shabi R, Bond A, Rieberer G. Homeopathic proving symptoms: result of a local, non-local, or placebo process? A blinded, placebo-controlled pilot study. Homeopathy. 2004; 93: 179-185.

[84] Dominici G, Dodesini M. Hydrogenium peroxydatum $-\mathrm{H}_{2} \mathrm{O}_{2}$ : proving results and clinical use of hydrogen peroxide in humans and animals [CDRom]. Oostende: 63 ${ }^{\text {rd }}$ Congress of LMHI; 2008.

[85] Pfrimmer D. Lactrodectus mactans tredecimguttatis? Non... Tarentula: conformation de la nouvelle hypothèse de Tarentula lycosa [CDRom]. Oostende: GIRI; 2008.
[86] Janssen JP. Homeopathic proving of Potentilla anserine: preliminary results [CD-Rom]. Oostende: GIRI; 2008.

[87] Lustig D. Plutonium's peaceful brother: Neptunium muriaticum [CD-Rom]. GIRI; 2008.

[88] Marim M. Brazilian pathogeneses and Evidence-Based Homeopathy [CD-Rom]. Oostende: GIRI; 2008.

[89] Ross A, Webster H, van der Hulst N. A homeopathic proving of Sutherlandia frutescens: its relationship to current indications and use and existing materia medica [CD-Rom]. Oostende: GIRI; 2008.

[90] Ross A, de Beer E. A 'family group analysis' (Sankaran) evaluation of a triple-blind homeopathic proving of Erythrina lysistemon (African coral tree [CD-Rom]. Oostende: GIRI; 2008.

[91] Scheepers L. Proving of Lobelia cardinalis [CDRom]. Oostende: GIRI; 2008.

[92] Scheepers L. Proving of Galium aparine [CDRom]. Oostende: GIRI; 2008.

[93] Vicol MI, Cristescu LM, Ivancius NV, Dobre ML, Sumbasacu M, Oprea AM, et al. Proving and case of Ytterbium nitricum [CD-Rom]. Oostende: GIRI; 2008.

[94] Imberechts J. International homeopathic provings, 2000-2008 (pathogeneses) [CD-Rom]. Oostende: GIRI; 2008.

[95] Van Wassenhoven M. Towards an evidencebased repertory: clinical evaluation of Veratrum album. Homeopathy. 2004; 93: 71-77.

[96] CCRH. Damiana: a multicentric clinical verification study. Indian J Res Homeopathy. 2007; 1(1): 17-23.

[97] Van Wassenhoven M. Retrospective LR study. Proceedings of the XIX GIRI Meeting; 2005; Monaco, France. Paris: GIRI; 2005. 24-35.

[98] Stolper CF, Rutten ALB, Lugten RFG, Barthels RJWM. Improving homeopathic prescribing by applying epidemiological techniques: the role of LR. Homeopathy. 2002; 91: 230-238.

[99] Rutten ALB, Stolper CF, Lugten RFG, Barthels RWJM. New repertory, new considerations. Homeopathy. 2008; 97: 16-21.

[100] Araujo C. Clinical verification of the pathogenetic symptoms of Anacardium, or regarding the general aspects of the human being) [CD-Rom]. Oostende: GIRI; 2008.

[101] Gnaiger - Rathmanmer J, Schneider A, Loader B, Böhler M, Frass M, Singer SR, et al. Petroleum: a series of 25 cases. Homeopathy. 2008; 97: 83-88. 
[102] Louis Ph. Douze cas d'eczema atopique guéris par Borax) [CD-Rom]. Oostende: GIRI; 2008.

[103] Petrucci R. Clinical confirmations of the proving of Falcon peregrinus disciplinatus) [CDRom]. Oostende: GIRI; 2008.

[104] Pla A. Clinical verification of Salix fragilis through two cases) [CD-Rom]. Oostende: GIRI; 2008.

[105] Servais PhM. Clinical verification of the symptoms of the materia medica of Petroleum) [CDRom]. Oostende: GIRI; 2008.

[106] Stolper E, Rutten L, Barthels R, Lugten R. Materia medica validation-course: learning from successful homeopathic treated cases) [CD-Rom]. Oostende: GIRI; 2008.

[107] Uyttenhove L. Clinical verification in dentistry) [CD-Rom]. Oostende: GIRI; 2008.

[108] Priorities and methods for developing the evidence profile of homeopathy: recommendations of the ECH General Assembly/XVIII Symposium of GIRI. Homeopathy. 2005; 94: 107-124.

[109] Chang FY, Lee SD, et al. Rat gastrointestinal motor responses mediated via activation of neurokinin receptors. J Gastroenterol Hepatol. 1999; 14: 39-45.

[110] Cristea A, Nicula S, Darie V. Pharmacodynamic effects of very high dilutions of belladonna on the isolated rat duodenum. In: Bastide M, editor. Signals and Images. Dordrecht: Kluwer Academic Publishers; 1997. 161-170.

[111] Schmidt F, SüB WG, Nieber K. In-vitro Testung von homöopathischen Verdünnungen. Biol Med. 2004; 1: 32-37.

[112] Belon P, Cumps J, Ennis M, Mannaioni PF, Roberfroid M, Sainte-Laudy J, et al. Histamine dilutions modulate basophil activation. Inflamm. Res. 2004; 53: 181-188.

[113] Sainte-Laudy J, Belon P. Improvement of flow cytometric analysis of basophil activation inhibition by high histamine dilutions: a novel basophil specific marker: CD 203c. Homeopathy. 2005; 95: 38.

[114] Sainte-Laudy J, Belon P. Use of four different flow cytometric protocols for the analysis of human basophil activation: application to the study of the biological activity of high dilutions of histamine. Inflamm Res. 2006; 55: S23-S24.

[115] Bastide M, Daurat V, Doucet-Jaboeuf M, Pelegrin A, Dorfman P. Immunomodulatory activity of very low doses of thymulin in mice. Int $J$ Immunotherapy. 1987; 3: 191-200.

[116] Weber S, Endler PC, Welles SU, SuanjakTraidl E, Scherer-Pongratz W, Frass M, et al. The effect of homeopathically prepared thyroxine on highland frogs: influence of electromagnetic fields. Homeopathy. 2008; 97: 3-9.

[117] Youbicier-Simo BJ, Boudard F, Mekaouche, M, Bastide M. Specific abolition reversal of pituitaryadrenal activity and control of the humoral immunity in bursectomized chickens through highly dilute bursin. Int J Immunopathol and Pharmacol. 1996; 9: 43-51.

[118] Eizayaga FX, Aguejouf O, Belon P, Doutremepuich C. Platelet aggregation in portal hypertension and its modification by ultra-low doses of aspirin. Pathophysiol Haemost Thromb. 2005; 34: 29-34.

[119] Agejouf O, Malfatti E, Belon P, Doutremepuich C. Time related neutralization of two doses acetyl salicylic acid. Thrombosis Res. 2000; 100: 317-323.

[120] Belougne-Malfatti E, Aguejouf O, Doutremepuich C, Belon P. Combination of two doses of acetyl salicylic acid: experimental study of arterial thrombosis. Thrombosis Res. 1998; 90: 215221.

[121] Aguejouf O, Malfatti E, Belon P, Doutremepuich C. Effects of acetyl salicylic acid therapy on an experimental thrombosis induced by laser beam. Thrombosis Res. 2000; 99: 595-602.

[122] Aguejouf O, Belougne-Malfatti E, Doutremepuich F, Belon P, Doutremepuich C. Thromboembolic complications several days after a single-dose administration of aspirin. Thrombosis Res. 1998; 89: 123-127.

[123] Doutremepuich C, Aguejouf O, Pintigny D, Serrillanges MN, De Seze O. Thrombogenic properties of ultra-low-dose of acetylsalicylic acid in a vessel model of laser-induced thrombus formation. Thrombosis Res. 1994; 76: 225-229.

[124] Vesvres MH, Doutremepuich F, Lalanne MCI, Doutremepuich CH. Effects of aspirin on embolization in an arterial model of laser-induced thrombus formation. Haemostasis. 1993; 23: 8-12.

[125] Lalanne MC, Ramboer I, De Seze O, Doutremepuich C. In vitro platelets/endothelial cells interactions in presence of acetylsalicylic acid at various dosages. Thrombosis Res. 1992; 65: 33-43.

[126] Doutremepuich C, De Seze O, Le Roy D, Lalanne MC, Anne MC. Aspirin at very ultra low dosage in healthy volunteers: effects on bleeding time, platelet aggregation and coagulation. Haemostasis. 1990; 20: 99-105

[127] Doutremepuich C, Pailley D, Anne MC, De Seze O, Paccalin J, Quilichini R. Template bleeding time after ingestion of ultra low dosages of acetyl salicylic acid in healthy subjects: preliminary study. Thrombosis Res. 1987; 48: 501-504. 
[128] Betti L, Brizzi M, Nani D, Peruzzi M. A pilot statistical study with homoeopathic potencies of Arsenicum album in wheat germination as a simple Model. British Homeopathic Journal. 1994; 83(4): 195-201.

[129] Betti L, Brizzi M, Nani D, Peruzzi M. Effect of high dilutions of Arsenicum album on wheat seedlings from seed poisoned with the same substance. British Homeopathic Journal. 1997; 86: 86-89.

[130] Betti L, Lazzarato L, Trebbi G, Brizzi M, Calzoni G L, Borghini F, et al. Effects of homeopathic arsenic on tobacco plant resistance to tobacco mosaic virus: theoretical suggestions about system variability, based on a large experimental data set. Homeopathy. 2003; 92: 195-202.

[131] Brizzi M, Lazzarato L, Nani D, Borghini F, Peruzzi M, Betti L. A biostatistical insight into the $\mathrm{As}_{2} \mathrm{O}_{3}$ high dilution effects on the rate and variability of wheat seedling growth. Forsch Komplement K Naturh. 2005; 12(5): 277-83.

[132] Brizzi M, Nani D, Peruzzi M, Betti L. Statistical analysis of the effect of high dilutions of arsenic in large dataset from a wheat germination model. British Homeopathic Journal. 2000; 89: 6367.

[133] Witt C, Bluth M, Albrecht H, Weißhuhn T, Baumgartner S, Willich S. The in vitro evidence for an effect of high homeopathic potencies: a systematic review of the literature. Complement Ther Med. 2007; 15(2): 128-138.

[134] Linde K, Jonas WB, Worke DMF, Wagner H, Eifel F. Critical review and meta-analysis of serial agitated dilutions in experimental toxicology. Human Exp Toxicol. 1994; 13: 481-492.

[135] COST (Cooperation in Science and Technology Research). Supplement of Report. Brussels : COST ; 1999 [updated 2005 Dec; cited 2008 Jan]. Available from: http://www.cost.esf.org.

[136] Alecu A, Alecu M, Cojocaru A, Brezeanu R. Effect of the homeopathic remedy Arnica montana $7 \mathrm{CH}$ on mechanical trauma in mice. Cultura Homeopática. 2007; 6(20): 16-18.

[137] Alecu A, Alecu M, Marcus G, Brezeanu R, Cojocaru A. Effect of the homeopathic remedies Arnica montana and Staphisagria on the time of healing of surgical wounds. Cultura Homeopática. 2007; 6(20): 19-21.

[138] Dos Santos AL, Perazzo FF, Cardoso LGV, Carvalho JCT. In vivo study of the antiinflammatory effect of Rhus toxicodendron. Homeopathy. 2007; 96: 95-101.

[139] Costa BGB, Siqueira CM, Barbosa GM, Portela MB, Soares RMA, Holandino C. Development of a new biotherapic of Candida albicans to the treatment of oral candidiasis using yeast cells cultures, placebo and Nystatin $\AA$ controlled design [CD-Rom]. Oostende: GIRI; 2008.

[140] Siqueira CM, Costa B, Amorim AM, Conzalvez M, Veiga VF, Lyrio C, et al. Looking for a new biotherapic prepared from infectious influenza virus: an in vitro study [CD-Rom]. Oostende: GIRI; 2008.

[141] Aslan S, Findik M, Kalender H, Celebi M, Izkür H, Handler J. Verbesserung der postpartalen Fertilität von Kühen durch Pulsatilla miniplex (Improvement of cows by Pulsatilla miniplex). Wiener Tierärztliche Monatsschrift. 2000; 87: 359362.

[142] Sekular PS, Dakshinder NP, Sarode DB, Rode AM, Kothedar MD. Evaluation of homeopathic drugs in hypogalactia of cows. Indian Vet J. 2000; 77: 813-814.

[143] Williamson AV, Mackie WL, Crawford WJ, Rennie B. A study using Sepia 200c given prophylactically postpartum to prevent anoestrus problems in dairy cows. British Homeopathic Journal. 1991; 80: 149-156.

[144] Searcy R, Reyes O, Guajardo G. Control of subclinical bovine mastitis. Utilization of a homeopathic combination. British Homeopathic Journal. 1995; 84: 67-70.

[145] Varshney JP, Naresh R. Comparative efficacy of homeopathic and allopathic systems of medicine in the management of clinical mastitis of Indian dairy cows. Homeopathy. 2005; 94: 81-85.

[146] Filliat C. Particularité de l'utilisation de l'homéopathie en production avicole. Proceedings of the Entretiens Internationaux de Monaco. 2002; Monaco, France. Paris: GIRI; 2002. 36-42.

[147] Riaucourt A. L'exemple de la filière porcine. Proceedings of the Entretiens Internationaux de Monaco. 2002; Monaco, France. Paris : GIRI; 2002. 52-58.

[148] Chaudhuri S, Varshney JP. Clinical management of babesiosis in dogs with homeopathic Crotalus horridus 200C versus allopathy. Homeopathy. 2007; 96: 90-94.

[149] Varshney JP. Clinical management of idiopathic epilepsy in dogs with homeopathic Belladonna 200 C: A case series. Homeopathy. 2007; 96(1): 46-48.

[150] Lira-Salazar G, Marines-Montiel E, TorresMonzon J, Hernandez-Hernandez F, Salas-Benito JS. Effects of homeopathic medications Eupatorium perfoliatum and Arsenicum album on parasitemia of Plasmodium berghei-infected mice (Malaria). Homeopathy. 2006; 95: 223-228. 
[151] Rajkumar R, Srivastava SK, Yadav MC, Varshney VP, Varshney JP, Kumar H. Effect of a homeopathic complex on oestrus induction and hormonal profile in anoestrus cows. Homeopathy. 2006; 95: 131-135.

[152] Berchieri A, Turco WCP, Paiva JB, Oliviera GH, Sterzo EV. Evaluation of isopathic treatment of Salmonella enteritidis in poultry. Homeopathy. 2006; 95: 94-97.

[153] Aboutboul R. Snake remedies and eosinophilic granuloma complex in cats. Homeopathy. 2006; 95: 15-19.

[154] Magnani P, Conforti A, Bellavite P. Effects of homeopathic drugs on the anxiety-like behaviour in mice [CD-Rom]. Oostende: GIRI; 2008.

[155] Boujedaini N. Action de Gelsemium sempervirens sur la synthèse d'allopregnanolone [CD-Rom]. Oostende: GIRI; 2008.

[156] Castilhos LR, Braga AB, Silva ALF, Teixeira LFA, Silva MGC, Souza JC. Effect of Arnica montana $200 \mathrm{CH}$ followed by Medicago sativa $6 \mathrm{CH}$ and Calcarea phosphorica $6 \mathrm{CH}$ usage in the feed consumption and weight gains of goat weaned kids [CD-Rom]. Oostende: GIRI; 2008.

[157] Weber S, Endler PC, Welles SV, SuanjakTraidl E, Scherer-Pongratz W, Frass M, et al. Thyroxine 30X, electromagnetic field influence (microwave, mobile phone, $\mathrm{x}$-ray) and highland frogs [CD-Rom]. Oostende: GIRI; 2008.

[158] Payen L. The effect of the homeopathic drug PVB ${ }^{\circledR}$ Phytolac in mastitis of cows [CD-Rom]. Oostende: GIRI; 2008.

[159] Issautier MN. Prevention of cold-intolerance in Guinea fowl by homeopathic treatment and analysis of its effects [CD-Rom]. Oostende: GIRI; 2008.

[160] Peychev L. Changes in rats learning and memory after a long treatment with four homeopathic medicines [CD-Rom]. Oostende: GIRI; 2008.

[161] Sommer MA, Blaha T. Epidemiological investigations on the use of homeopathic remedies in swine under special consideration of the comparison of homeopathic and antimicrobial therapies [CD-Rom]. Oostende: GIRI; 2008.

[162] Zalla Neto R, Bonamin LV. Lymphoid response and granuloma development in mice inoculated with BCG and treated with Thymulin in homeopathic preparations [CD-Rom]. Oostende: GIRI; 2008.

[163] Filtchev S, Nestorov I, Grondeo D, Ivanov M. Les possibilites de l'homéopathie dans la prévention et dans le traitement de l'asthme chez les enfants atopiques [CD-Rom]. Oostende: GIRI; 2008.
[164] Ketata ML, Villano G, Bensalah-Mezghanni S, Pellegrini A, Hayouni A, Mtiraoui A. Asthme allergique et therapeutique homeopatique (à propos de six cas) [CD-Rom]. Oostende: GIRI; 2008.

[165] Jurj Gh. Homeopathic treatment of atopic dermatitis [CD-Rom]. Oostende: GIRI; 2008.

[166] Popowski P. Dermatite atopique et récherche clinique en médecine ambulatoire [CD-Rom]. Oostende: GIRI; 2008.

[167] Marijnen $\mathrm{Ph}$, Fayard AL. Hypericum perfoliatum et Lucite estivale benign: de l'observation véterinaire à l'indication therapeutique [CD-Rom]. Oostende: GIRI; 2008.

[168] Camacho C, Lozano S, Melo M, Pedraza C, Vanegas S, Benítez G, et AL. Effectiveness of homeopathic medicine Arnica $7 \mathrm{CH}$ vs. naproxen on postoperative extraction of third molar including pain relief [CD-Rom]. Oostende: GIRI; 2008.

[169] Clercq JM, Capieaux E, Jenaer M. Microimmunotherapy applied to periodontal diseases [CD-Rom]. Oostende: GIRI; 2008.

[170] Tiba HS, Contin I, Itagaki C, Wierzchon LMRS, Fachada AP, Feighelstein GA. Application of homeopathy in patients of TMD (têmporomandibular disorder) and orofacial pain [CD-Rom]. Oostende: GIRI; 2008.

[171] Chiche JL. Benefits of Actaea racemosa 30C in cervical dystocia [CD-Rom]. Oostende: GIRI; 2008.

[172] Dungler T, Bordet MF. Benefits of Sanguinaria canadensis $7 \mathrm{C}$ in the treatment of flush [CD-Rom]. Oostende: GIRI; 2008.

[173] Masson JL, Colas A. Homeopathic treatment of hot flushes in menopausal women [CD-Rom]. Oostende: GIRI; 2008.

[174] Honneger F, Lavallee V, Aguerre C, Cresp C, Desmonty-Minjon ML, Doussin-Dirks A, et al. Mycoses vaginales recidivantes et traitement homéopathique: un travail prospectif [CD-Rom]. Oostende: GIRI; 2008.

[175] Roca M. Treatment of prolactinoma with homeopathy [CD-Rom]. Oostende: GIRI; 2008.

[176] Shangloo GK, Shangloo S, Shangloo S. Homeopathic cure of uterine fibroid and ovarian cyst [CD-Rom]. Oostende: GIRI; 2008.

[177] Shukla P, Misra RK. Breast lumps and homeopathic management: a critical evaluation on the basis of fine aspiration cytology and radiological techniques [CD-Rom]. Oostende: GIRI; 2008.

[178] Grelle L. Thyroid nodules: homeopathic treatment of subclinical hypothyroidism [CD-Rom]. Oostende: GIRI; 2008. 
[179] Baroli A. Microimmunotherapy applied to autoimmune thyroid pathologies: clinical cases of chronic thyroiditis [CD-Rom]. Oostende: GIRI; 2008.

[180] Arjoun H, Demonceaux A, Monastiri K. Bronchiolitis in infants and homeopathy [CD-Rom]. Oostende: GIRI; 2008.

[181] Bahloul H, Musial E, Mahfoudh A. Homeopathic treatment of varicella in children (about 16 cases) [CD-Rom]. Oostende: GIRI; 2008.

[182] Fayard AL. Two examples of clinical research. eye irritation [CD-Rom]. Oostende: GIRI; 2008.

[183] Rusev DS. Sulphur iodatum: subsidiary homeopathic medicine in infectious diseases of children [CD-Rom]. Oostende: GIRI; 2008.

[184] Bolognani F, Mendes F, Kede J, Mendes P. Homeopathy: study based on clinical observations: therapeutic with homeopathy [CD-Rom]. Oostende: GIRI; 2008.

[185] Bolognani F, Mendes MF, Mendes PA, Kede J, Maia AP. Relation between Plumbum metallicum and progressive spinal amiotrophy [CD-Rom]. Oostende: GIRI; 2008.

[186] Bolognani F, Mendes E, Martins S, Maia AP, Serpa C, Damasceno AM, et al. Attention déficit disorder [CD-Rom]. Oostende: GIRI; 2008.

[187] Mateescu R. Attention deficit hyperactivity disorder in children and homeopathic treatment [CD-Rom]. Oostende: GIRI; 2008.

[188] Damaceno AMG. Homeopathic treatment in a study of infantile cerebral palsy [CD-Rom]. Oostende: GIRI; 2008.
[189] Serpa C, Bolognani F, Maia AP, Mendes F, Damasceno AM, Durão F. Homeopathic treatment for cognitive disturbances in patients with cerebral paralysis [CD-Rom]. Oostende: GIRI; 2008.

[190] Kivellos S, Papatriantafyllou J, Papilas K, Vithoulkas G, Karagerorgiou K. Practising clinical homeopathy in a headache clinic of a major public hospital in Athens, Greece: 4-year experience in treating migraine patients [CD-Rom]. Oostende: GIRI; 2008.

[191] Martins S, Bolognani F, Maia AP, Serpa C, Damasceno AM, Mendes MF. Coreoathetosis condition and homeopathy [CD-Rom]. Oostende: GIRI; 2008.

[192] Mendes MF, Bolognani F, Carillo R, Gosik MS, Parkinson's disease: homeopathic therapy [CDRom]. Oostende: GIRI; 2008.

[193] Teixeira MI, Bolognani F, Maia AP, Serpa C, Martins S, Mendes MF. Spastic condition and homeopathy [CD-Rom]. Oostende: GIRI; 2008.

[194] Roberfroid M, Cumps J, Henry MF, Jenaer M. Microimmunotherapy and treatment of multiple sclerosis: results of a clinical trial [CD-Rom]. Oostende: GIRI; 2008.

[195] Pevenage S. Veterinary practice with nonconventional therapies in oncology [CD-Rom]. Oostende: GIRI; 2008.

[196] Khuda-Bukhsh AR. Can homeopathy ameliorate the suffering of arsenic victims? A simplistic approach in the management of a menacing rural health problem [CD-Rom]. Oostende: GIRI; 2008.

\section{(c)) BY-NC-ND Licensed to GIRI}

Support: author declares that this study received no funding

Conflict of interest: author declares there is no conflict of interest

Revised 15 June 2008; Published: 30 June 2008

Revised version of presentation at 63rd Congress of LMHI, Oostende, May 20-24th, 2008

Erratum: 30 Dec 2008. (http://www.feg.unesp.br/ ojs/zacha_ijhdr/erratum/?v=7\&i=23\&pi=72)

Correspondence author: Michel van Wassenhoven, michelvw@homeopathy.be

How to cite this article: Wassenhoven MV. Scientific framework of homeopathy: Evidence-based Homeopathy. Int J High Dilution Res [online]. 2008 [cited YYYY Mmm DD]; 7(23): 72-92. Available from:

http://www.feg.unesp.br/ ojs/index.php/ijhdr/article/view/286/354. 